\title{
In-Between Images: Where is the Ground?
}

\author{
Andrea Thoma \\ University of Leeds (United Kingdom) \\ E-mail: a.thoma@leeds.ac.uk
}

\begin{abstract}
Joan Jonas's large survey exhibition at Tate Modern (2018) highlighted the contemporary relevance of this pioneer of performance art in her juxtapositions of analogue and virtual methods. Her process often relies on a ground or stage where physical remnants of her performances are tangible. Drawing from these insights and exploring figure-ground relations through a selection of works by various artists and filmmakers, this article aims to challenge Hito Steyerl's polemic that we might not need a ground within contemporary virtual image worlds. The consideration of case studies will be informed by philosophical reflections as to the relevance and scope of the idea of ground within the post-digital era.
\end{abstract}

Keywords: Figure-ground, intermediality, performance art, installation, post-digital.

Hito Steyerl wrote: "in many of these new visualities, what seemed like a helpless tumble into an abyss actually turns out to be a new representational freedom. And perhaps this helps us get over the last assumption implicit in this thought experiment: the idea that we need a ground in the first place" (2011, e-flux). Steyerl refers here to contemporary visual representations that are marked by a "delinearization of horizons and perspectives" (2011, e-flux) such as multiple-screen installations or various 3D-technologies, suggesting that the lack of a determined ground, despite the vertigo that it might cause, could be an opportunity for new configurations. Whilst acknowledging the tremendous opportunities within the accelerating pace of visual modalities supported through ever more advanced technology, this article advocates that we very much need some form of ground as a means to allow for the physicality of the body to inform the virtual worlds of the digital realm.

The argument takes inspiration from the work of Joan Jonas and of Hito Steyerl, and sets out to explore how intermediality within a fine art context continues to draw on influences from 70s performance and installation art. By considering a selection of key artworks involving both a visceral and conceptual 
relation to the idea of a ground, the article aims to dispute Steyerl's polemic that our reliance on a ground might not be necessary when navigating through contemporary image worlds.

As an opening to the discussion, it is worth visualizing in one's mind's eye the renowned work by Henri Matisse The Red Studio (1911) - the ground in this extraordinary painting is an abstraction, its flatness and colour resembling the actual ground of Australian desert scenes ${ }^{1}$ as it might be captured as electronic (low-resolution) image by a satellite camera. With Matisse, it is the ground of red paint that holds the image together. ${ }^{2}$ It is material, substance and colour as light. The figure-ground relation in this iconic painting is quite radical for the beginning of the twentieth century. We are here close to the monochrome, were it not for the perspectival lines of the drawing and the few objects that furnish the pictorial space, the latter paradoxically suggesting both flatness and perspectival depth of field.

The idea of ground within art theory and practice has been and continues to be interpreted in relation to cognitive, phenomenological and philosophical parameters. Its representation has undergone significant challenges in times of technological, socio-cultural and political change, in particular in the era of digital imaging. This paper will examine how our understanding of a ground within image scenarios, may these be virtual or actual, has shifted considerably from the idea of "ground as visual and conceptual reference," towards a perception of multi-dimensional imagery in digital media applications that create a "free fall" scenario as Steyerl (2011) would claim.

In art works defined by the era of the post-digital (accepting a pervasive digital culture) (Cramer 2016), ${ }^{3}$ the idea of "a ground" seems more and more irrelevant, or is replaced by groundlessness (Steyerl 2011) as we move from window to

1 Michelangelo Antonioni was equally taken by the idea of a red painterly ground as the setting for a scene in his film Red Desert (1964). [Fig. 1.] Inspired by paintings by Mark Rothko, he used monochrome backdrops for the filmic narrative (Fer 2004, 172). Briony Fer observes, "the red interior of the hut provides a highly abstract pictorial ground on which they [the characters] can act" (172).

2 Painter Patrick Heron was profoundly moved by The Red Studio describing its ground, "I made frequent visits to gaze at the wonderful expanses of the soft red which covers this canvas from top to bottom and from corner to corner, and which itself created the most profound sensation of space. Space in colour! The red is indefinable. In certain areas you fancy it is approaching scarlet, while in others it almost appears a dull purple or even a brownish crimson [...] It revolutionised my existence" (1995).

3 Florian Cramer explains how the term post-digital was initially coined in 2000 in the context of electronic music implying a critical stance towards the idea of advancement associated with digital technology. The term resurfaced in 2012 when Allessandro Ludovico suggested that print and electronic media were not antagonistic but that new juxtapositions of analogue and digital were called for. Ludovico agreed with postdigital musicians that digital technology did not imply "progress and future per se" (Cramer 2016, 59). 
window, from click to click, scrolling endlessly through visuals and textual data. As we zoom in and out of maps of Google Earth (or similar software applications), whilst rotating, moving and flicking from satellite to street views, our virtual body becomes apparatus. We adopt the perspective of the surveillance camera, observing from outer space, or from various locations on the ground - a ground that easily morphs into another view, another window, or that disappears just as easily with a mouse click. Steyerl points to the precariousness of such a ground. "Just as linear perspective established an imaginary stable observer and horizon, so does the perspective from above establish an imaginary floating observer and an imaginary stable ground." (2011, e-flux.)

In Between-the-Images, Raymond Bellour (2012) mentions how video had "opened passageways" when referring to its ability of generating an awareness of what might happen between different media, obtaining different qualities of images. Technology has moved on considerably since the original publication of L'Entre-Images: Photo, Cinéma, Vidéo (Bellour 1990) and it is now the visual effects of data streaming, satellite imagery and surveillance software applications that still imply a sense of novelty. However, Bellour's interest in what happens between images as a result of juxtaposing different media is as relevant as ever: "this is how images now come to us: within the space where we must decide which of them are real images. That is to say a reality of the world, as virtual and abstract as it may be, reality of an image-as-possible-world" (Bellour 2012, 17).

It is precisely because our image perception and understanding of image production has undergone (and continues to do so) such dramatic changes in a context of accelerated image inflation within the digital circuits of the Internet, that we need to claim the scope that lies within a juxtaposition of the analogue and the virtual, as inbetweenness of images, to offer a recovery of the ground.

Whilst acknowledging the liberating qualities of "groundlessness" as recognized by philosophers such as Ernesto Laclau (Steyerl 2011, e-flux), ${ }^{4}$ the argument that I wish to put forward highlights the importance of material presence and of phenomenology as experienced through visual modes such as performance, sculpture, painting and drawing. I argue that it is through a juxtaposition of these

4 Olivier Marchart elaborates on post-foundationalism as a continuous questioning of "metaphysical figures of foundation" claiming that what is at stake is not the absence of ground but ground as finality. "The ontological weakening of ground does not lead to the assumption of the total absence of all grounds, but rather to the assumption of the impossibility of a final ground, which is something completely different as it implies an increased awareness of, on the one hand, contingency and, on the other, the political as the moment of partial and always, in the last instance, unsuccessful grounding." $(2007,2$. 
analogue modes with the virtual image worlds of the post-digital, and equally with the close-circuit television processes of early video experimentation, that we can re-think the ground as that which allows us to be embodied.

In order to elucidate the points of discussion, reference will be made to some key artworks that focus on the in-between of images through a juxtaposition of visual methods; these include Joan Jonas's Stream of River, Flight or Pattern (2016-17) and Lines in the Sand (2002), Joseph Beuys's Dernier espace avec introspecteur/ Letzter Raum mit Introspekteur (1964-1982) and Richtkräfte (1974), Eija-Liisa Ahtila's The House (2002), Hito Steyerl's In Free Fall (2010) and Johanna Reich's A Drone Painting / Black Square on White Ground (2016).

\section{Joan Jonas and Inbetweenness}

Joan Jonas is a video and performance pioneer who has been celebrating inbetweenness as her main modus operandi since the 1960s. Her art practice encompasses video, drawing, storytelling, performance, dance and sculpture to convey, transcribe, juxtapose and animate an eclectic repertoire of signs in view of developing her personal take on mythological narration. The artist explains how her work is "all about layering" and how this process is an analogy for the simultaneity of thought and how one image might call for another (Jonas 2016).

Her recent retrospective at Tate Modern (2018) highlights how a process that stems from a late sixties/early seventies engagement with performance art has profound relevance within the contemporary context of ubiquitous digitization and virtual reality. As Jonas negotiates relations between analogue and digital, she reminds us of the potential to access information through body, that is, through the awareness of physical presence. The latter is particularly evident in her reliance on drawing, both actual and virtual. Similarly, her frequent use of the mask, costume or various props as extension or disconnection of the body/self highlight the empowering aspect of metamorphosis or transformation within a performative application of image-making. Despite her background in sculpture, Jonas recognizes being influenced by pictorial space, in particular the space within renaissance painting. "Renaissance painting has always been one of my inspirations, and I've seen those gridded devices they looked through to analyze an image [...] When I started making video, I thought of how to look at a picture, how to look at a framed image and how do you place things in that frame to create the illusion of space. But Renaissance paintings always have the illusion of space, created by the development of perspective.” (Lissoni and Lorz 2018, 250.) 
Jonas's Lines in the Sand (2002) was shown at Tate Modern (2018) but was initially presented at Documenta 11 as installation and later also as performance. ${ }^{5}$ In the space at Tate Modern, Jonas uses objects that seem both sculptures and props, a green wooden couch, a black board with a projection where Jonas is drawing on a board, a metal cone, some prints of photographs that her grandmother took in Egypt on the wall. The video on the main wall shows Jonas enacting the narrative of the Trojan War transferred to Las Vegas. She recites a poem by American poet Hilda Doolittle who narrates the ancient story from Helena's perspective but sets the scene in Egypt. Another smaller video, Pillow Talk, is shown in one of her My New Theater boxes (Lissoni and Lorz 2018). Jonas explains that she enacts a grand historical event by using texts from different cultures and periods, her own personal objects, her own body, and Las Vegas as a place of contemporary cultural symbolism (Wulffen 2002, 267).

In Lines in the Sand, Jonas creates an arrangement of multiple signifiers, where the multi-layered narrative seems spun across a space that seems like a stage set with filmed performances of her reciting poetry and drawing, still images and objects placed on a slightly elevated platform - a stage. And yet, it provides the ground, the centre of gravity, both for the installation and the performance of the same name. Acatia Finbow (2016) explains how Jonas adapted the role of Helen by inserting aspects of her own biography including her grandmother's travels to Egypt in 1910. By juxtaposing a mythological figure with her own story she reflects on aspects of identity. The space of the museum offers a context where "reality and representation, history and myth are presented and juxtaposed" (Finbow 2016). The installation Stream of River, Flight or Pattern (2016-17) equally uses drawing as a means of grounding images to convey a haptic and cognitive experience. The idea of bird flight gives the space an aerial quality where paper kites are hung from the ceiling. Line drawings of birds on wooden panels are interspersed with video projections that show layered filmed footage of landscapes and figures performing in front of a projected scene thus becoming part of a shadow play (Lissoni and Lorz 2018). [Fig. 2.]

In Jonas's performances and installations her video imagery is always linked to the tangibility of haptic experience thus providing a physical and conceptual grounding particularly through drawing/writing, sculpture and dance.

$5 \quad$ See: Images of Lines in the Sand (2002) projected during the keynote speech by Joan Jonas at Media Art History RE-CREATE 05. 11. 2015: https://www.youtube.com/watch? $v=G j i h 3 N 7 n z o I \& t=2353$ s. Last accessed 17. 07. 2019. 


\section{Hito Steyerl's Free Fall in View of Philosophical Considerations of Ground}

Hito Steyerl is a filmmaker and writer who examines our engagement with digital networks such as the Internet whilst challenging the control mechanisms of big media society. In her installations and filmic works she explores relations between the game industry, surveillance and documentary strategies to reflect how we navigate between images and how we might defy being caught up within surveillance control systems. ${ }^{6}$ In her essay In Free Fall: A Thought Experiment on Vertical Perspective (2011) Steyerl ponders how the "new visualities" of advanced technology, as found in the satellite and drone imagery of aerial mappings, the multi-dimensional topographies of video games or diverse imaging software applications, have caused a considerable shift in how we engage with perspective, making her question if we still need a ground. Steyerl's argument focuses on a philosophical understanding and challenge of a ground, a terra firma, as an existential and ontological frame of reference to our being-in-the-world. Considering its analogies in the visual arts within the scope and limitations of linear perspective, she observes how perception has evolved to a multi-layered or multi-focused perspective. She points to the contemporary philosophical trope of "groundlessness" as argued by Ernesto Laclau, who claims the absence of ground can function as a potential facilitator of an "experience of freedom." However, in view of this absence of ground, we are bound to experience, even if momentarily, an impression of falling, of being adrift. "We cannot assume any stable ground on which to base metaphysical claims or foundational political myths. At best, we are faced with temporary, contingent, and partial attempts at grounding. But if there is no stable ground available for our social lives and philosophical aspirations, the consequence must be a permanent, or at least intermittent state of free fall for subjects and objects alike. But why don’t we notice?" (Steyerl 2011.)

As filmmaker, Steyerl has engaged with these ideas of ground and free fall in an exploration of the plane/wreckage as symbol (of the rise and fall) of capitalist economy, where both film industry and metal recycling plants partake in an exchange of value. Her multi-channel installation In Free Fall (2010) reflects on grounded planes in relation to their partaking in an economy of transport, on the blowing up of discarded planes to provide footage for Hollywood films,

6 See her video piece How Not to be Seen: A Fucking Didactic Educational.MOV File (2013) for a humorous take on how to use various strategies of camouflage to disappear from the "radar" of satellite cameras. 
and on the recycling of the plane wreckages to generate raw materials for the production of DVDs. ${ }^{7}$

Gil Leung (2010) comments on Steyerl's installation: "falling is a transition. It is a movement from one position to another. In as much as it suggests failure or ruin, to love is also to fall. It is corruption, revolution and abandonment. It implies a relationship. Hito Steyerl's In Free Fall charts a singular object, the Boeing 707-700 4X-JYI airplane, in this process of falling." Steyerl presents us with a double bill. Whereas her installation uses documentary and fictional elements to engage in narrative tropes of free fall, the essay of the same title is presented as "a thought experiment in vertical perspective" offering a philosophical contextualization. Daniel Rourke observes how Steyerl instrumentalizes the idea in both. Commenting on Steyerl's anecdote about how pilots in free fall situations get confused about their identity in relation to the plane, he explains how "the pilot and the plane things are sensed as one object, mutually falling to earth. Without an anchor, perspective itself should not be trusted" (Rourke 2013, 22).

Returning to the idea of ground as terra firma, in The Origin of the Work of Art, Martin Heidegger disputes this concept by presenting an abyss, a ground that is beyond the ground, a "withdrawal of ground" or Ab-grund, showing how the earth might provide a (misleading) sense of grounding. The ground that is presented by the earth is "no stable and present terra firma but always a groundless ground" (Mitchell 2010, 212). Heidegger argues that what the earth supports lies in a phenomenology of appearance. As Andrew J. Mitchell explains, "if what appears were tied to a substance beneath it, it would never be free to reach out to appeal to us" $(2010,212)$.

In his essay Restitutions of the Truth in Pointing (pointure), Jaques Derrida (Kamuf 1991, 305) offers another angle to Heidegger's concept of ground ${ }^{8}$ and absence-of-ground (Bodenlosigkeit) when discussing a correspondence between the latter and the art historian Meyer Shapiro regarding a painting by Van Gogh. We learn that Heidegger considers the translation of the Greek hypokeimenon to the Latin subjectum as a loss of ground, or of context, of the original Greek understanding of ground as having something underneath (Kamuf 1991, 305). For Heidegger, "the absence of ground (Bodenlosigkeit) of Western thought opens with this translation" (Kamuf 1991, 305). Hence, here the ground involves

7 See: Picture This, http://www.picture-this.org.uk/worksprojects/works/by-date/2010/in-freefall. Last accessed 19. 07. 2019.

8 Derrida refers to Meyer Shapiro's essay The Still Life as a Personal Object, where Shapiro writes a critique of Heidegger's observations on Van Gogh's shoes in The Origin of the Work of Art. (See note, Kamuf 1991, 279.) 
cultural context and groundlessness or Bodenlosigkeit the loss of that context. Derrida explains, "at the very moment when he calls us back to the Greek ground and to the apprehension of the thing as hypokeimenon, Heidegger implies that this originary state still covers over something [...] The hypokeimenon, that underneath, hides another underneath. And so the Latin underneath (substantiasubjectum) causes to disappear, along with the Greek ground, the Greek underneath (hypokeimenon)" (Kamuf 1991, 308). While Heidegger refers here to an ideality, let us consider how physical experience of ground is conditioned by conceptual differentiation.

\section{The Actual Ground Experienced through Body}

Gilles Deleuze highlights how the differentiation of the virtual, not as groundlessness but as differentiation of ground, and thus as ground-in-themaking offers further insights as to the potential of how we experience the actual ground. "The Deleuzean virtual is thus not the condition of possibility of any rational experience, but the condition of genesis of real experience [...] the virtual, as genetic ground of the actual, cannot resemble that which it grounds; thus, if we are confronted with actual identities in experience, then the virtual ground of those identities must be purely differential." (Protevi and Smith 2018.) These reflections indicate how for Deleuze, a conceptual, virtual dimension is necessary to generate or define a physical encounter with ground.

Within the plethora of artists exploring the material encounter or immersion with the ground, it is important to mention two iconic examples for their direct, uncompromising engagement. In his performance Seedbed at Ileana Sonnabend Gallery in 1972, Vito Acconci offered a literal take on the ground as Ab-grund when he masturbated below a ramp responding to the visitors as they negotiated the space above him..$^{9}$ In contrast, Ana Mendieta tried to merge her body with the soil in some of her ritualistic performances that address taboos related to the female body (Grosenick 2001, 342). Here the figure becomes part of the ground, claiming her belonging to the earth as in Flowers on Body (1973) thus reinforcing a bond with the ground. Helena Reckitt describes how in her earth performances, Mendieta aims at a "dissolution that implicates a rebirth through reintegration with the maternal body of the earth" (Reckitt 2001, 98). Here, the body of the artist merges with the ground to embrace the earth as maternal force.

9 See also Vito Acconci: Seedbed, 1972. https:/www.moma.org/collection/works/109933. Last accessed 19. 07. 2019. 
German artist Joseph Beuys was part of the Fluxus movement in the sixties and was dedicated to creating a "social sculpture" based on his expanded idea of plasticity and of art as social and political activity where everyone is considered an artist. ${ }^{10}$ Whilst the socio-historical and political context of his work differs greatly from Jonas, both artists have a practice rooted in sculpture, using performance, drawing and other visual methods to engage with aspects of mythology and referring to the natural elements, including the earth as ground. The reception of Beuys's creation of a personal mythology has though caused some controversy, in particular regarding his ahistorical stance despite his work clearly responding to a particular historical period. ${ }^{11}$ With his consideration of the healing power of materials, Beuys engaged in a shamanistic deployment of symbolic form. At the same time, he promoted relations between art and politics wanting to create art as "social sculpture." Beuys's installation Richtkräfte/ Directing Forces (1974) indicates a coming together of image, text and materiality to generate a conceptual and material ground. It is based on 100 black boards that he used during a lecture/performance at the ICA in London in the context of the exhibition Art into Society - Society into Art. When he finished writing on a panel, Beuys fixed the chalk-written text on the black board and threw it on the ground. As the boards piled up, they ended up covering the ground, or constituting a new ground including the writing and the implied concepts (Stüttgen 1993, 148). The installation is presented on a slightly elevated platform. Except for three boards displayed on easels, the rest of them are now stacked horizontally, covering the ground that becomes residue of object, text and performance. The title is based on one of the boards, which has the inscription Richtkräfte einer neuen Gesellschaft (Directing Forces of a New Society) as heading (Stüttgen 1993, 150) and aims to challenge conventions arguing for a remaking of ground. [Fig. 3.]

In Dernier espace avec introspecteur/Letzter Raum mit Introspekteur (1982), ${ }^{12}$ the chair at the centre of the spatial arrangement, which recalls Beuys's Fettstuhl

10 Beuys expands the notion of sculpture (Plastik) as "constellation of forces" (Kräftekonstellation) consisting of "undefined, chaotic and undirectional energies, a crystalline principle of form and a mediating principle of movement" (von unbestimmten, chaotischen, ungerichteten Energien, einem kristallinen Formprinzip und einem vermittelnden Bewegungsprinzip). With this expanded understanding of sculpture and art in general, Beuys wants art to remedy the ills of society and call this undertaking of bringing about social and political change "social sculpture" (soziale Plastik) (Boehlen 1993, 278-279).

11 Benjamin Buchloh comments, "the private and public mythology of Joseph Beuys, to give an example from art history, could only be developed and maintained on the ahistoricity of aesthetic production and consumption in post-war Europe” $(2007,110)$.

12 This installation was initially shown at Durand-Dessert Gallery in Paris in 1982, then in the same year at Anthony D’Offay in London and is now at the Staatsgalerie Stuttgart (Zweite 1991, 31). 
(1964), ${ }^{13}$ introduces the idea of a potential figure, seated. On the ground, there are also two larger wax wedges with "chalice-like" forms attached to their top like chimneys on a roof, amidst boards of plaster and rubble indicating the process of casting. The space is traversed by iron pipes covered in felt, suggesting movement and tension (Zweite 1991, 31). The gallery floor provides the ground for this "last" space in the series of Beuys's environments; it functions as stage set, as sculptural field, a space that we look back into through a mirror. The centre of the mirror is marked with a cross, a recurring sign in Beuys's iconography. On the wall behind the actual mirror, is a photograph depicting the same mirror but shown in another sculptural context. The mirror also suggests introspection, as Beuys does not use the French word rétroviseur but calls it introspecteur, (Zweite 1991, 33). Whilst in this sculptural configuration there are no filmic or digital scenarios, the mirror still involves the idea of the Deleuzian/Bergsonian virtual - as that which is not actual but reflects the actual. ${ }^{14}$ Within this spatial arrangement of sculptural form, the ground, as with Matisse, crucially holds the scene together where sculptural tropes such as measure, gravity and construction/destruction are put in relation with each other.

In contrast to the tangibility and reference to a ground in the sculptural installations of Beuys and the performances of Joan Jonas, Eija-Liisa Ahtila's 3-channel installation The House (2002) engages in a situation where the perception of the reliability of ground is compromised by the collapse of ordinary time-space relations as a result of psychosis. Elisa, the main and only character within the narrative, is shown driving through a Nordic landscape to arrive at her house. The viewer accompanies her on a journey of uncertain and shifting boundaries, from her flight through the forest, to a cow entering the living room of her house, to her effort of covering the windows to shut out images - which seem to intrude from the world outside but really are projections from inside her mind. For Elisa, the interior of the house seems uncertain in its boundaries and untrustworthy as shelter. As she prepares the curtains, she seems to struggle keeping her balance suggesting the ground has become unreliable, "as if the floor, too, has lost its natural solidity" (Bal 2013, 98). As the viewer partakes in the changing scenery, they are amid the three-folded space of the

13 Whereas the Fettstuhl of 1964 was covered with a wedge of fat, in this installation, the wedge is cast wax.

14 Deleuze explains the crystal image, "in Bergsonian terms, the real object is reflected in a mirrorimage as in the virtual object which, from its side and simultaneously, envelops or reflects the real: there is 'coalescence' between the two. There is a formation of an image with two sides, actual and virtual" (1989, 66-67). 
triptych, ${ }^{15}$ confronted with the uncertainties of ground. This is accentuated by the discrepancies between sound and image, and also through the juxtaposition of different realities - actual, perceived and remembered.

Steyerl (2011) comments on a perception of "groundlessness" in the "new visualities" and multiplicities found in the screen images of digital surveillance technology, which have done away with the modalities of linear perspective. With Ahtila, the ground and its absence or precariousness is not suggested through the fast pace and spatial simultaneity of Internet applications, but is defined by images that are evocative of the symptoms of psychosis. She endeavours to reflect on how the mind works and claims that this is only possible through the complexity of multi-channel installations. ${ }^{16}$

There is a scene where Elisa flies over treetops. It is both exhilarating and disconcerting. Mieke Bal observes how we witness here a discrepancy between the elation within the image of flying and the fear of not regaining the ground. "The fantasy of flying recedes when the viewer's awareness of the woman's mature age combines with her attempts to get back onto the ground, so that her grounding becomes a problem. In fact, it is when that grounding becomes a problem that the theme of madness comes into play." (Bal 2013, 86-87.)

Whilst Ahtila is concerned with states of mental illness and the loss of ground she depicts within Elsa's character is symptomatic of the psychotic condition of the latter, one might argue that The House is indicative of a more general need to catch up with the body, a body ungrounded in its effort to keep up to speed with the ever accelerating image flow of the contemporary world.

Hannah Reich instrumentalizes digital technology whilst emphasizing the importance of embodiment through processes such as painting, performance and projection of digital imagery on actual bodies. Reich describes how her filmic work A Drone Painting/Black Square on White Ground (2016) refers to the iconic painting by Kazimir Malevich. She considers that his intention to "free art from the weight of things resonates with the post-digital era and the associated disappearance of the real" (Günzel 2017, 228). ${ }^{17}$ In Reich's work, a drone films the artist dressed in black while she paints a black square on a white canvas

15 Mieke Bal comments on the open nature of the triptych and how the three-channel installation echoes the walls of the house, which have become permeable $(2013,108)$.

16 Daniel Birnbaum refers to her conception of time in his Chronology, "the format of a traditional feature film can never reflect how perception and memory works, says Ahtila" (2011, 68).

17 Author's translation. "Wenn Malevich davon spricht 'die Kunst vom Gewicht der Dinge zu befreien' scheint mir das interessanterweise sehr nah am postdigitalen Zeitalter zu sein, das vom Verschwinden des Realen markiert wird." 
stretched out on some grassland. Reich finally disappears into the square, as the camera technology is unable to clearly distinguish ${ }^{18}$ between black paint and black clothing (Günzel 2017, 228). [Figs. 4-5.]

Here we have a ground that is multilayered, the ground of grassland, where the canvas is placed. We also understand the canvas as ground for the figure of the painted black square and the black square as ground for the actual figure of the artist's body - and all of this together becomes the ground down there filmed from above. When discussing her work, Reich speaks of "a longing for the haptic" (Sehnsucht nach dem Haptischen) as she describes the use of materials such as canvas and paint contrasting the surveillance technology of the drone (Günzel 2017, 228).

\section{Conclusion}

The objective of this discussion was to claim that we do need a ground, particularly in the post-digital era, a ground that facilitates the experience of the haptic. By considering a range of artworks and how they rely or challenge the idea of ground, one could argue that our understanding of ground is manifold and constantly in flux - as solid entity, as frame of reference, as space that is both backdrop and the substance that holds different visual elements together, as the space between images or as philosophical idea. Where Steyerl speaks of ground or groundlessness in relation to an aesthetics of digitization and multi-perspectival design software, Jonas works with a ground that refers as much to her background in sculpture and to the spatio-temporal situation of the object as it engages with ideas of the "stage set" (Lissoni and Lorz 2018, 237) and with early Renaissance perspective, but equally with the psychological dimension of figure-ground relations.

Even though the discussion of a ground involves ideas of perspective and its undoing or relativization through multiple viewpoints, Margaret Iversen reminds us that basic human psychological perception is quite different from images of linear perspective (and one might add from its multiperspectival digital scenarios), "for, paradoxically, our modern perceived reality has become so thoroughly conditioned by perspectival forms of representation, including photography, that we are likely to miss the point, which is that modern perspective abstracts

18 It is worth pointing to the problematic of figure-ground recognition in Computer Science where the concept relates to the technicalities within an economy of digital imaging. Here, the emphasis lies not on the philosophical or aesthetic aspect of figure/ground relations but on how "different categories of objects" might be recognized to allow for "scene understanding" (Carreira and al 2011). 
fundamentally from basic human psycho- physiological perception, which is obviously not monocular or static or strictly geometrical” $(2005,196)$.

The ground as concept and as physical tangible entity is a crucial frame of reference that provides context whilst at the same time enabling us to take a departure towards image worlds of groundlessness. An analogy of this can be found in Rosalind Krauss's reference to the demarcations of a pool. When advocating the white cube exhibition space as essential frame of reference for the viewing of contemporary art practice, ${ }^{19}$ Krauss uses the image of the swimmer pushing away from the wall of a pool to gain momentum. "The white cube is the base we touch with our eyes, the way the edge of the pool is the surface against which we kick in order to propel ourselves back through the water.” $(2011,86$. If we apply this metaphor to our dealings with the ground, we might similarly be able to claim that keeping the ground as backdrop within the equation heightens the impetus towards the open-endedness of multi-perspectival and multidimensional image scenarios.

With a loss of ground, we are in free fall, entering multi-perspectival dimensions which are generated by the computation of algorithms - and yet, there is scope to accommodate and juxtapose the image-worlds of technology with haptic visual and sonic modes that allow us to create integrated circuits where a phenomenology of perception based on actual embodiment connects with the realm of virtual reality.

\section{References}

Bal, Mieke. 2013. Thinking in Film: The Politics of Video Art Installation According to Eija-Liisa Ahtila. London: Bloomsbury.

Birnbaum, Daniel. 2005. Chronology. New York: Lukas \& Sternberg.

Boehlen, Marc. 1993. Plastik. In Joseph Beuys: 26. November 1993 bis 20. Februar 1994, ed. Harald Szeemann, 148-151. Zürich: Kunsthaus Zürich.

Buchloh, Benjamin. 2007. Beuys: The Twilight of the Idol. In Joseph Beuys: The

Reader, ed. Claudia Mesch and Viola Michely, 109-126. London: Tauris.

Carreira, João, Fuxin Li and Cristian Sminchisescu. 2011. Object Recognition by Sequential Figure-Ground Ranking. International Journal of Computer Vision (2012) 98: 243-262.

19 One might contest the claim for the white cube as essential exhibition space and there are ample examples of exhibition strategies that would confirm its limitations. However, using the white cube as frame of reference, and be it to highlight differences with post-curatorial strategies, remains a useful exercise. 
Cramer, Florian. 2016. Nach dem Koitus oder nach dem Tod:Zur Begriffsverwirrung von 'Postdigital', 'Post-Internet' und 'Post-Media' [After Coitus or After Death: The Conceptual Confusion of Postdigital, Post-Internet and Post-Media]. Kunstforum International vol. 242: 54-67.

Deleuze, Gilles. 1989. Cinema 2: The Time-Image. London: Athlone.

Finbow, Acatia. 2016. Joan Jonas, Helen in Egypt: Lines in the Sand 2004, case study, Performance At Tate: Into the Space of Art, Tate Research Publication. https://www.tate.org.uk/research/publications/performance-at-tate/casestudies/joan-jonas-helen-in-egypt. Last accessed 19. 07. 2019.

Grosenick, Uta. 2001. Women Artists in the $20^{\text {th }}$ and $21^{\text {st }}$ century. Köln, London: Taschen.

Günzel, Ann-Katrin. 2017. Johanna Reich: Gruss an eine Welt, in der die Sehnsucht nach dem Haptischen wieder auflebt [Johanna Reich: Greetings to a World in Which the Yearning for the Haptic Revives]. Kunstforum International vol. 245 (March-April): 226-235.

Heron, Patrick. 1995. Patrick Heron on Matisse's The Red Studio. The Guardian Dec 5, 1995.

Iversen, Margaret. 2005. The Discourse of Perspective in the Twentieth Century: Panofsky, Damisch, Lacan. Oxford Art Journal vol. 28, no. 2: 193-202.

Krauss, Rosalind E. 2011. Under Blue Cup. Cambridge: MIT Press.

Joan Jonas Interview: Layers of Time. 2016. https://www.youtube.com/ watch? $v=W I S I Y E 4 d O K w$. Last accessed 19. 07. 2019.

Leung, Gil. 2010. After before now: Notes on In Free Fall. http://www.picturethis.org.uk/library/essays1/2010/after-before-now-notes-on-in-free-fall. Last accessed 19. 07. 2019.

Lissoni, Andrea and Julienne Lorz. 2018. Joan Jonas. Munich: Hirmer.

Marchart, Oliver. 2007. Post-Foundational Political Thought: Political Difference in Nancy, Lefort, Badiou and Laclau. Edinburgh: Edinburgh University Press.

Mitchell, Andrew J. 2010. The Fourfold. In Martin Heidegger: Key Concepts, ed. Bret W. Davis, 208-218. Durham: Acumen.

Reckitt, Helena, ed. 2001. Art and Feminism. London: Phaidon.

Rourke, Daniel. 2013. Falling into the Digital Divide: Encounters with the Work of Hito Steyerl. Afterimage vol. 40, no. 5: 19-22.

Smith, Daniel and John Protevi. 2018. Gilles Deleuze. Stanford Encyclopedia of Philosophy. https://plato.stanford.edu/entries/deleuze/. Last accessed 19. 07. 2019. 
Steyerl, Hito. 2011. In Free Fall: A thought experiment on vertical perspective. e-flux Journal no. 24(April). https://www.e-flux.com/journal/24/67860/in-freefall-a-thought-experiment-on-vertical-perspective/. Last accessed 19. 07. 2019. Stüttgen, Johannes. 1993. Richtkräfte. Joseph Beuys, Rauminstallationen [Directing Forces: Joseph Beuys, Room Installations]. In Joseph Beuys: 26. November 1993 bis 20. Februar 1994, ed. Harald Szeemann, 148-151. Zürich: Kunsthaus Zürich.

Wulffen, Thomas. 2002. Documenta11: Der Rundgang [Documenta 11: The Tour]. Kunstforum International vol. 161: 114-415.

Zweite, Arnim. 1991. Natur Materie Form. II. Vom ‘dernier espace...' zum ‘Palazzo Regale’: Die letzten Räume von Joseph Beuys [Nature Matter Shape. II. From 'dernier espace...' to 'Palazzo Regale:' The Last Rooms of Joseph Beuys]. In Joseph Beuys: Natur Materie Form, 30-53. München: Schirmer Mosel.

\section{List of Figures}

Figure 1. Scene from Michelangelo Antonioni's Red Desert (Il deserto rosso, 1964) with main characters in front of red ground (they later will partly dismantle the wooden walls by tearing away the red boards).

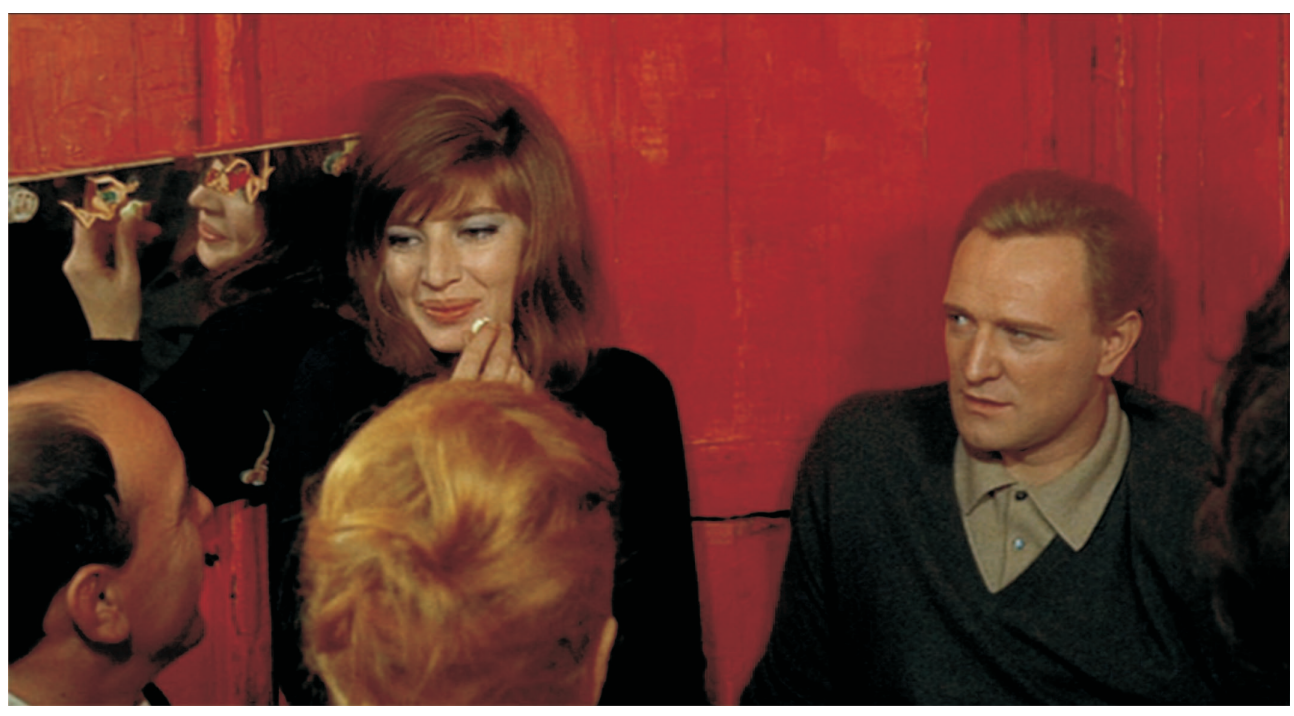


Figure 2. Stream of River, Flight or Pattern (2016-17). (Still part of the video advertising Joan Jonas's retrospective at Tate Modern in 2018: https://www. youtube.com/watch?v=rzp6Ehnxq34. Last accessed 17. 07. 2019.)

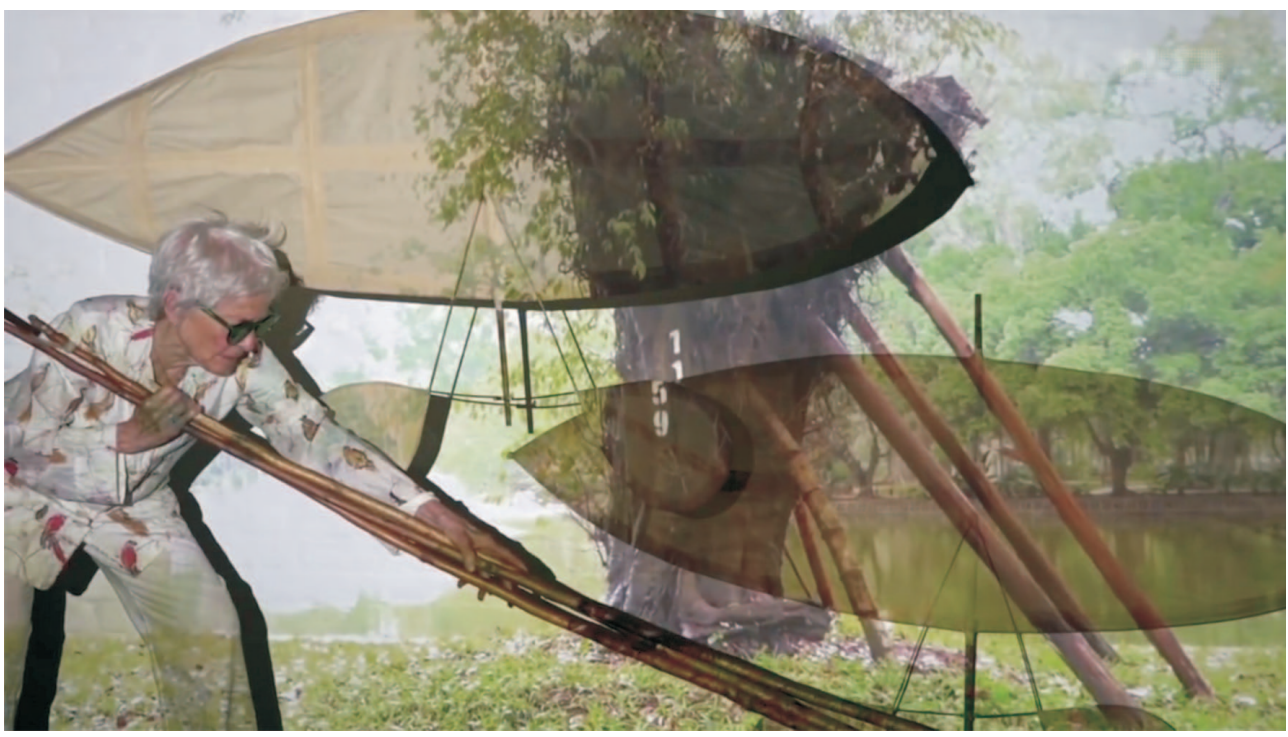

Figure 3. Joseph Beuys, Richtkräfte (1974) exhibited at Hamburger Bahnhof, Berlin. (Source: https://www.youtube.com/watch?v=im2pqMlVSj8. Last accessed 19. 07. 2019.)

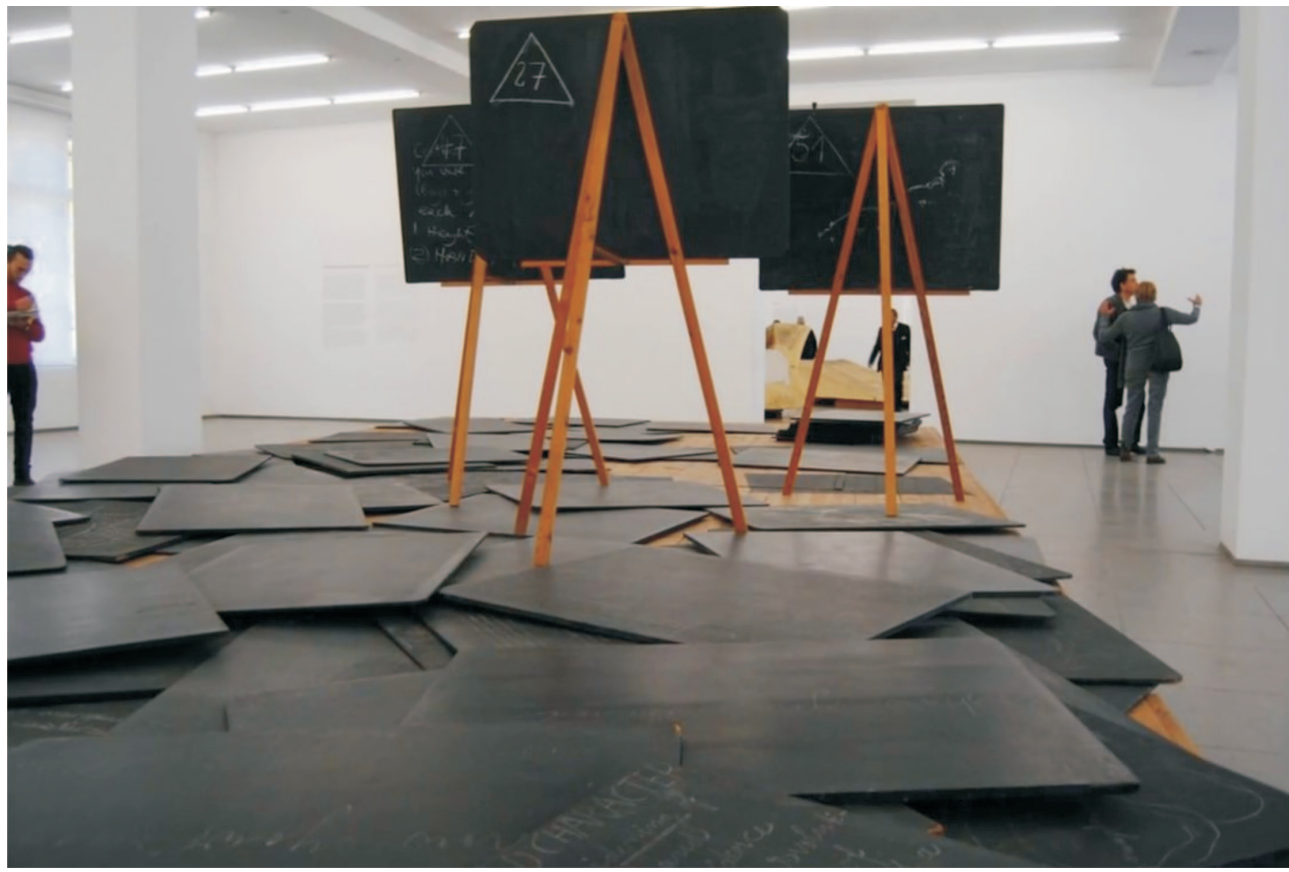


Figures 4-5. Images from Hannah Reich's performance/film A Drone Painting/Black Square on White Ground (2016), https://www.youtube.com/ watch?v=KrNjFxRkZgc. Last accessed 19. 07. 2019.
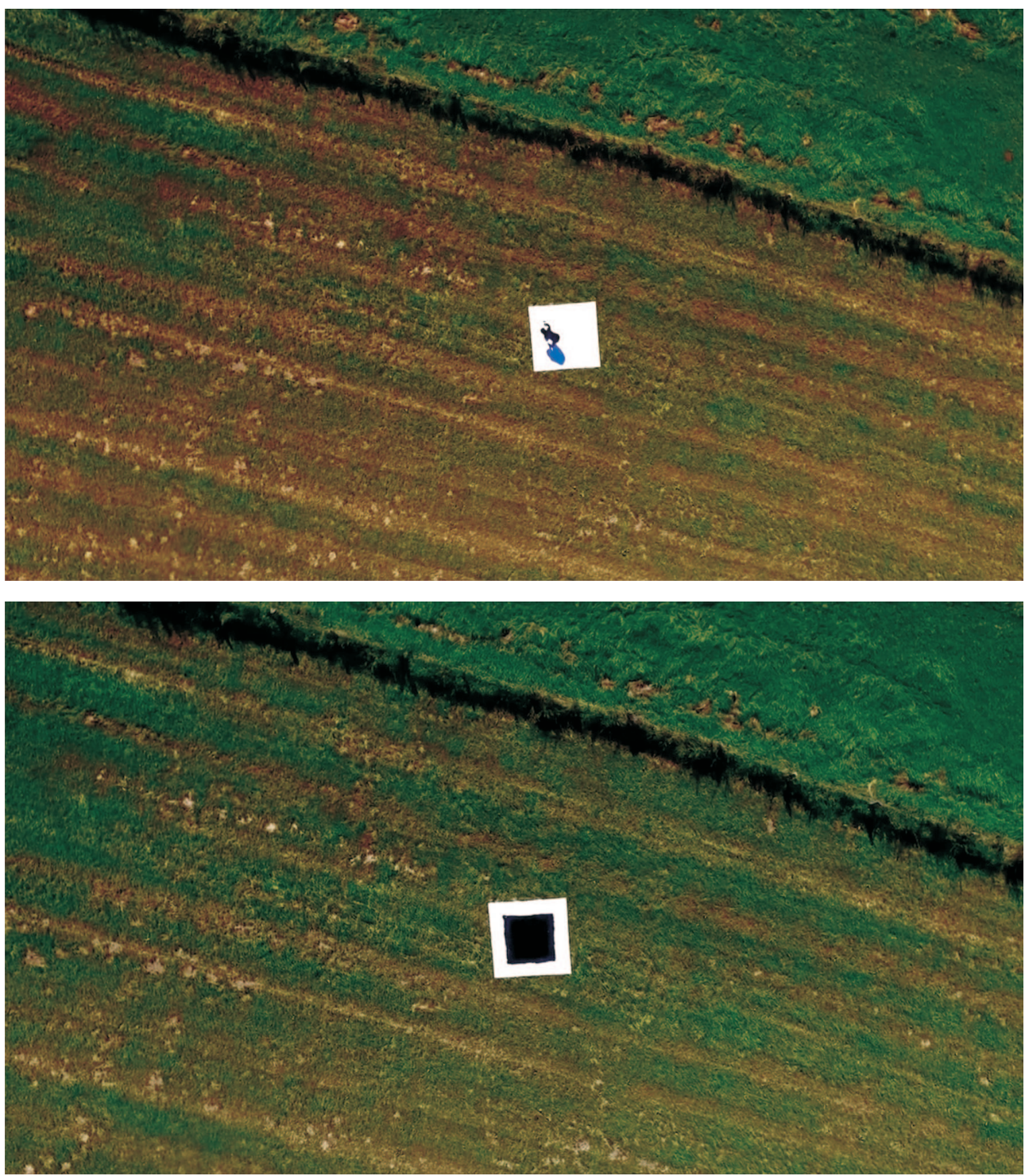